\title{
Assessment of Indoor Radon Concentrations in Dwellings for Baghdad Governorate by Using RAD-7 Detector
}

\author{
Mahmood S. Karim, Hasan H. Daroysh, Ali N. Mohammed \\ Department of Physics, College of Education, Al-Mustansiriyah University, Baghdad, Iraq \\ Email: Mahmood_msc74@yahoo.co.uk
}

Received 24 February 2016; accepted 25 April 2016; published 28 April 2016

Copyright (C) 2016 by authors and Scientific Research Publishing Inc.

This work is licensed under the Creative Commons Attribution International License (CC BY).

http://creativecommons.org/licenses/by/4.0/

(c) (i) Open Access

\begin{abstract}
In the present work, radon gas concentrations in different dwellings in Baghdad governorate are measured by using RAD-7 detector. The results have shown that, the radon gas concentrations ranged between $\left(40.67 \pm 3.1 \mathrm{~Bq} / \mathrm{m}^{3}\right)$ to $\left(190.00 \pm 2.7 \mathrm{~Bq} / \mathrm{m}^{3}\right)$ with an average value $(113.66 \pm 30.2$ $\left.\mathrm{Bq} / \mathrm{m}^{3}\right)$; in the first one we draw the map radiations for indoor radon gas concentrations in Baghdad governorate. We would like to mention that the present study is considered to be very important and vital because it is concerned with people health and safety in the first place.
\end{abstract}

\section{Keywords}

Radon, Dwellings, RAD-7 Detector, CR-39, Indoor Radon Concentration, Baghdad Governorate

\section{Introduction}

Radon $\left({ }^{222} \mathrm{Rn}\right)$ is a radioactive gas with a half-life of (3.82 d). It is produced by the decay of naturally occurring radionuclide $\left({ }^{226} \mathrm{Ra}\right)$, which was decay product in the uranium $\left({ }^{238} \mathrm{U}\right)$ series. Thoron gas $\left({ }^{220} \mathrm{Rn}\right)$, which is a radon isotope, is a decay product in the thorium $\left.{ }^{232} \mathrm{Th}\right)$ series. The half-life of thoron is (56 s) which is much shorter than that of radon. Because of such a short half-life of thoron, its emanation from building materials, as well as, its infiltration from the ground and further migration is restricted to a few centimeters only. When radon is inhaled into the lungs it decays by means of alpha-emission which causes ionization damage when it strikes the lung tissue. Over time, this damage causes lung cancer [1] [2]. The radon concentration in air varies in accordance with location, high level of the houses, material of the houses built, different room in the same house, and ventilation rate [3]. Radon exhalation rates in the areas, where uranium deposits and phosphate rocks located, are significant, and this is the main source of exposure to uranium. Long-term exposure to elevated levels of ra- 
don increases risk of containing lung cancer. The purpose of this study is to gather information about the natural radiation and to evaluate the Radon concentration throughout. This is motivated by the concern about the possible consequences of long term exposure to higher concentration of radon and its short-lived product in air [4].

\section{Experimental Procedure}

\section{A-The Detector}

The RAD-7 is a true, real-time continuous radon monitor. This means that a varied radon concentration level can be observed during a measurement period. This is very helpful, in the sense that one can investigate the factors influencing the radon concentration with time. The factors may include temperature changes, wind speeds, relative humidity and may even give insight into air movements in a room [5]. Figure 1 shows RAD-7 electronic continuous radon monitor.

Sniff mode and circle time was set to be 1 hour in accordance with running time of each path of the valve. In order to investigate radon released from the sample to air, the sample was enclosed into a column and airborne radon was measured with a continuous monitor of electrostatic type (RAD-7, Durridge company, USA). The experimental setup shown in Figure 2 shows the schematic diagram RAD-7-Air in dwellings.

The air flow rate was $0.7 \mathrm{~L} \cdot \mathrm{min}^{-1}$. Room air was drawn from the inlet and radon generated in the air flow system was measured with the RAD-7. The measurement interval was 1 hour. The sample weight was different from sample to sample [6].

\section{Results and Discussion}

In this work measurement the radon gas concentrations in different dwellings in 50 locations for Baghdad governorate. Table 1 presents the radon gas concentrations in indoor dwellings in 50 locations for Baghdad governorate. From Table 1 it can be noticed that, the highest average radon gas concentration in air in dwellings was found in Shaab city which was $\left(190.00 \pm 2.7 \mathrm{~Bq} / \mathrm{m}^{3}\right)$, while the lowest average radon gas concentration was found in AL-Karada city which was $\left(40.67 \pm 3.1 \mathrm{~Bq} / \mathrm{m}^{3}\right)$, see Figure 3, with an average value of $(113.66 \pm 30.2$ $\mathrm{Bq} / \mathrm{m}^{3}$ ) and see Figure 4 shows that the in the first one the map radiations for indoor radon gas concentrations by using the RAD-7 detector in Baghdad governorate, all radon gas concentrations in Baghdad governorate was less than the lower limit of the recommended ranged $\left(200-300 \mathrm{~Bq} / \mathrm{m}^{3}\right.$ ) (International Committee on Radiation Protection ICRP, 2009) [7]. Finally, we would like to mention that the present study is considered to be very important and vital because it is concerned with people health and safety in the first place, and to the best of our knowledge.

\section{Conclusion}

The results have shown that, the radon gas concentrations ranged between $\left(40.67 \pm 3.1 \mathrm{~Bq} / \mathrm{m}^{3}\right)$ to $(190.00 \pm 2.7$ $\left.\mathrm{Bq} / \mathrm{m}^{3}\right)$ with an average value $\left(113.66 \pm 30.2 \mathrm{~Bq} / \mathrm{m}^{3}\right)$. All the results in the present work which were lower

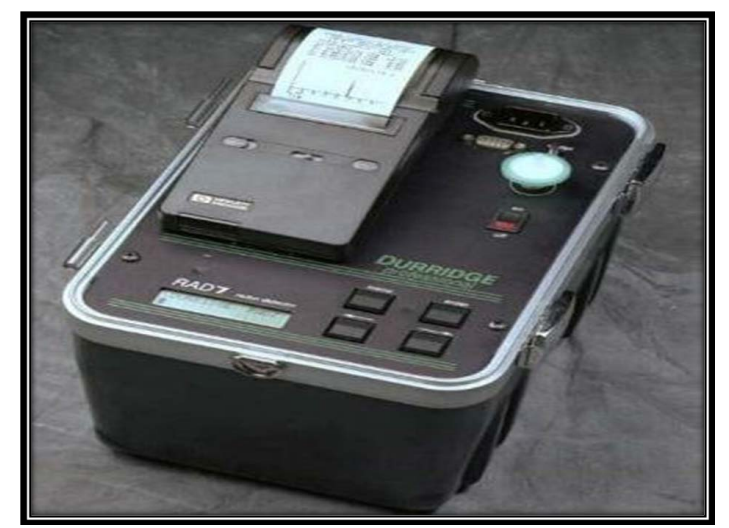

Figure 1. The durridge RAD-7 electronic continuous radon monitor with an HP printer mounted for immediate printing of results. 


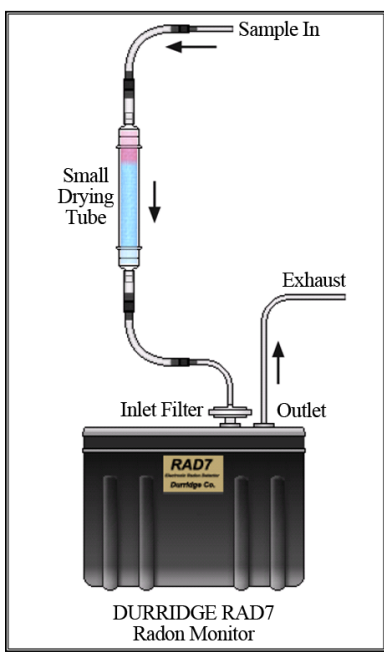

Figure 2. Schematic diagram for the Radon measurement in indoor air.

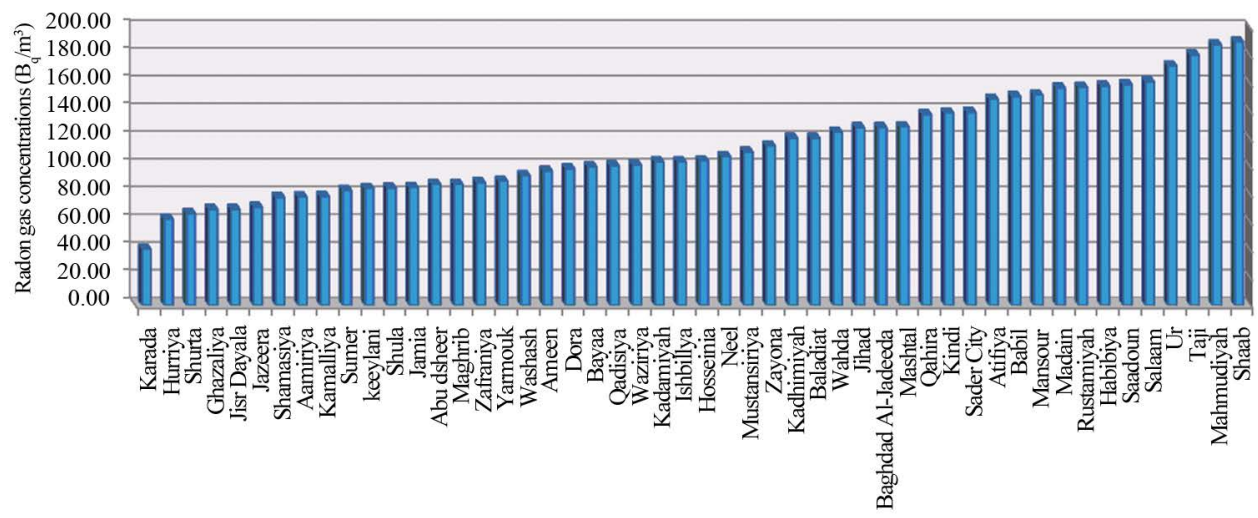

Figure 3. Schematic diagram for the Radon measurement in indoor air.

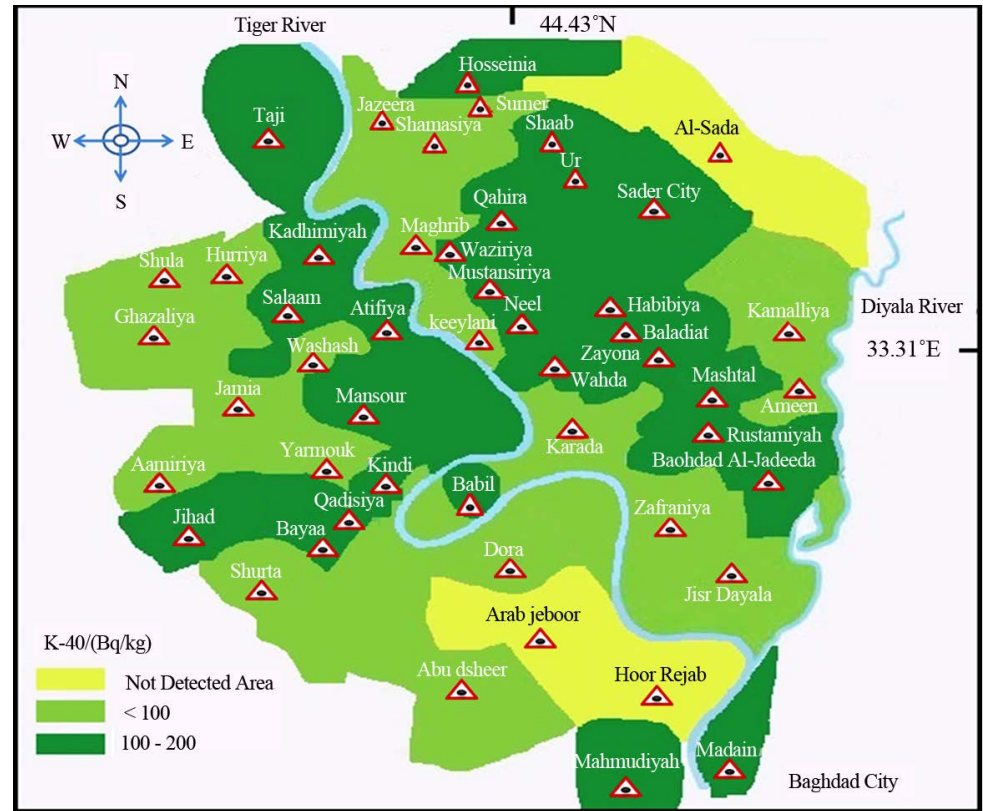

Figure 4. Sketch map showing locations for the studied sites in Baghdad governorate. 
Table 1. The radon gas concentrations $\left(\mathrm{C}_{\mathrm{Rn}}\right)$, in dwellings in Baghdad governorate.

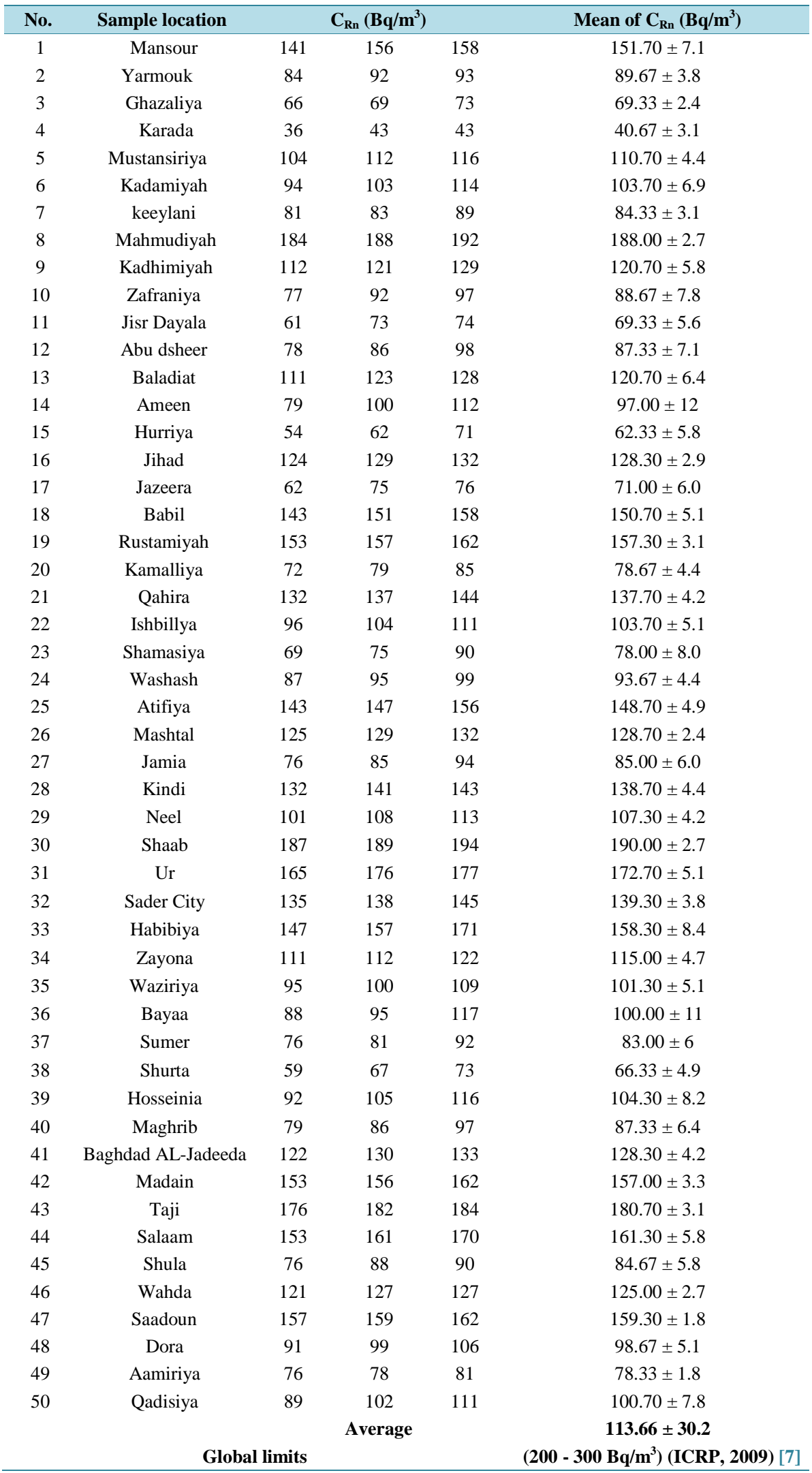


than the ranged $\left(200-300 \mathrm{~Bq} / \mathrm{m}^{3}\right.$ ) recommended by (International Committee on Radiation Protection, ICRP in 2009).

\section{Acknowledgements}

The authors are thankful to the residents of the Baghdad governorate for their co-operation during the fieldwork.

\section{References}

[1] Guo, Q., Shimo, M., Ikebe, Y. and Minato S. (1992) The Study of Thoron and Radon Progeny Concentrations in Dwellings in Japan. Radiation Protection Dosimetery, 45, 357-359.

[2] Forkapic, S., Bikit, I., Conkic, LJ., Veskovic, M., Slivka, J., Krmar, M., Zikic-Todorovic, N., Varga, E. and Mrđa, D. (2006) Methods of Radon Measurement. Physics, Chemistry and Technology, 4, 1-10. http://dx.doi.org/10.2298/fupct0601001f

[3] Durrani, S.A. and Ilic, R. (1997) Radon Measurements by Etched Track Detectors. Applications in Radiation Protection. Earth Science and the Environment, Singapore.

[4] Soharabi, M. and Solamanian, A. (1988) Indoor Radon Levels in Some Regions of Iran. Nuclear Tracks and Radiation Measurements, 15, 616.

[5] Hayes, R. and Cheng Chiou, H. (2003) Preliminary Evaluation of Real Time False CAM Alarm through Continuous Radon Monitoring. Health Physics, 84, 589-592.

[6] Durridge Company Inc. (2010) Reference Manual Version 6.0.1, RAD-7 Electronic Radon Detector.

[7] ICRP (International Commission on Radiological Protection Statement on Radon) (2009) ICRP, Ref. 00/902/09. 